\title{
Development of nanotechnology-based drug delivery systems with olive vegetable oil for cutaneous application
}

\author{
Silas Arandas Monteiro e Silva ${ }^{1}$, Rísia Lacerda², Jéssica Bernegossi ${ }^{3}$, Marlus Chorilli \\ Gislaine Ricci Leonardi, ${ }^{4, *}$
}

\author{
${ }^{1}$ Medicine Department, Federal University of São Paulo, UNIFESP, São Paulo, Brazil, ${ }^{2}$ Pharmacy Course, Methodist \\ University of Piracicaba, UNIMEP, Piracicaba, Brazil, ${ }^{3}$ School of Pharmaceutical Sciences, São Paulo State University, \\ UNESP, Araraquara, Brazil; ${ }^{4}$ Institute of Environmental, Chemistry and Pharmaceuticals Sciences, Federal University of São \\ Paulo, UNIFESP, Diadema, Brazil
}

Liquid-Crystalline Systems represent active compounds delivery systems that may be able to overcome the physical barrier of the skin, especially represented by the stratum corneum. To obtain these systems, aqueous and oily components are used with surfactants. Of the different association structures in such systems, the liquid-crystalline offer numerous advantages to a topical product. This manuscript presents the development of liquid-crystalline systems consisting, in which the oil component is olive oil, its rheological characterizations, and the location of liquid crystals in its phase map. Cytotoxic effects were evaluated using J-774 mouse macrophages as the cellular model. A phase diagram to mix three components with different proportions was constructed. Two liquid crystalline areas were found with olive oil in different regions in the ternary diagram with two nonionic surfactants, called SLC1 (S1) and SLC2 (S2). These systems showed lamellar liquid crystals that remained stable during the entire analysis time. The systems were also characterized rheologically with pseudoplastic behavior without thixotropy. The texture and bioadhesion assays showed that formulations were similar statistically $(p<0.05)$, indicating that the increased amount of water in S2 did not interfere with the bioadhesive properties of the systems. In vitro cytotoxic assays showed that formulations did not present cytotoxicity. Olive oil-based systems may be a promising platform for skin delivery of drugs.

Uniterms: Liquid-Crystalline Systems/development. Liquid-Crystalline Systems/reology. Drugs/skin delivery. Olive Oil/use/Liquid-Crystalline Systems. Rheology. Cytotoxicity. Bioadhesion.

Os cristais líquidos representam um sistema de liberação de substâncias ativas capazes de vencer a barreira cutânea, representada especialmente pelo estrato córneo. Água, óleo e tensoativos são misturados para se obter esses sistemas. Diferentes estruturas podem ser formadas nesses sistemas, as quais oferecem muitas vantagens para os produtos de uso tópico. Esse trabalho visou ao desenvolvimento de sistemas líquido-cristalinos preparados com óleo de oliva, sua caracterização reológica e a identificação das fases cristalinas no diagrama ternário. Efeitos citotóxicos foram avaliados usando células de rato como modelo celular. Construiu-se um diagrama de fases que mistura três componentes em diferentes proporções. Duas áreas de cristal líquido, denominadas SLC1 (S1) e SLC2 (S2), foram encontradas com óleo de oliva em diferentes regiões no diagrama ternário preparado com dois diferentes tensoativos não-iônicos. Esses sistemas mostraram fase cristalina lamelar, que permaneceu estável durante o tempo estudado. Os sistemas foram também caracterizados reologicamente e apresentaram comportamento pseudoplástico com tixotropia. Os ensaios de textura e bioadesão mostraram que as formulações foram similares $(\mathrm{p}<0.05)$, indicando que o aumento da quantidade de água em S2 não interferiu nas propriedades bioadesivas dos sistemas. Os ensaios de citotoxicidade mostraram que as formulações não foram citotóxicas. Sistemas à base de óleo de oliva são interessantes para a liberação de fármacos na pele.

Unitermos: Sistemas líquido-cristalinos/desenvolvimento. Sistemas líquido-cristalinos/reologia. Fármacos/liberação na pele. Óleo de oliva/uso/Sistemas líquido-cristalinos. Reologia. Citotoxicidade. Bioadesão.

\footnotetext{
*Correspondence: G. R. Leonardi. Departamento de Medicina. Universidade Federal de São Paulo - UNIFESP. Rua São Nicolau, 210, 09913-030 - Diadema - SP. E-mail: grleonardi@hotmail.com
} 


\section{INTRODUCTION}

The main difficulty of active substances, to diffuse through the skin, is due the structure and lipid composition of the epidermis, more specifically due to the stratum corneum. As a consequence, many studies in the pharmaceutical and cosmetic area have been conducted in the search for the development of complex emulsion systems able to promote the release of active compounds, in such a way to overcome the barriers of skin permeation that limit the use and effectiveness of numerous compounds active in topical formulations (Leonardi, Gaspar, Maia Campos, 2002; Elias, 2005).

When the subject is emulsion systems for active substances, it is conceivable to consider the tendency of self-organization of amphiphilic molecules constituents of such systems. From this point of view, it is possible to recognize and identify structures of intermediate characteristics between the solid and liquid matter state, more commonly known as liquid crystals (LCs), (Nesseem, 2001; Muller-Goymann, 2004; Bechtold, 2005; Souza et al., 2012; Santos et al., 2013). Thus, LCs have been characterized by presenting a intermediate molecular order degree (Bechtold, 2005; Tyle, 1989; Santos et al., 2005).

The LCs can be classified in two types: Thermotropic and Lyotropic according to their frmation. The first kind result from phase transitions due to temperature variations. The lyotropic LCs are characterized by being formed in the presence of two components: an organic compound (such as a surfactant) and a polar solvent; in the majority of cases water; although organic solvents of extreme polarity, e.g. glycerol, ethylene glycol etc give liquid crystals. In emulsion preparations with Liquid Crystals, the latter can take different structural forms as: lamellar; Hexagonal and Cubic (Bechtold, 2005; Formariz et al., 2005; Chorilli et al., 2011).

To form Liquid-Crystalline Systems three generic components are necessary: Aqueous phase; an oily phase and a surfactant (s). Studies on LCs reinforce the dominant influence of the nature of the oil phase and surfactants used to ensure the formation of these mesogen structures. Thus, among the numerous options of lipophilic compounds that can be employed in the preparation of SLCs, one can highlight vegetable oils. Among these, the olive oil is gaining prominence, when considering their use in the cosmetic area. Among the active components, studies show the presence of phenolic compounds, including hydroxytyrosol, with antioxidant activity can prevent cellular changes and to prevent the formation of radicals capable of damaging cellular protein structures (Tofani et al., 2010; D'Angelo et al., 2005; Visioli, Bellomo, Galli, 1998; Visioli, 1999; Visioli et al., 2001.

The rheology is described as being the science of the deformation and flow of matter subjected to stress under certain conditions over a time period (Rebello, 2005; Almeida; Bahia, 2003; Brummer; Godersky, 1999). This study is extremely comprehensive, involving aspects related to viscosity, flow type, elasticity and sensory aspects relevant to the topical products (Chorilli et al., 2007). Additionally, through rheological studies one can ensure that the consistency and spreadability formulations are reproduced from lot to lot, ensuring the technical quality of the finished product (Corrêa et al., 2005).

The present study aimed to develop liquid crystalline systems formed with olive oil, through the ternary diagram, investigate the maintenance of liquid crystal in formulations after 30 days of preparation, as well as to evaluate the rheological behavior thereof.

\section{MATERIAL AND METHODS}

\section{Reagents}

Non-ionic surfactants polyoxyethylene 20 sorbitan monooleate (Tween ${ }^{\circledR} 80$ ), sorbitan monooleate (Span 80) (Chemicals MERCK - Germany) were used as surfactants. The oil phase was olive oil, and the aqueous phase was distilled water.

\section{Ternary diagram and aqueous titration for obtaining liquid-crystalline systems}

The ternary diagram was constructed by combining the oil phase with the aqueous phase in order to obtain a region of translucent systems, representing liquid crystalline systems. The design and graphical representation of the ternary diagram was performed using the software Sigmaplot version 11.0. The systems were prepared by aqueous titration method, in which olive oil is mixed with the surfactant combination of sorbitan monooleate and polyoxyethylene 20 sorbitan monooleate in $1: 3$ proportion, followed by addition of water at increasing concentrations.

Each sample was homogenized by vortexing for 30 seconds, being classified as: transparent/translucent, gel, turbid, viscous, milky liquid and phase separation in time T24 hours.

\section{Small-Angle X-Ray Scattering (SAXS)}

The SAXS studies were placed in the D11-A 
Measurement Station from the National Laboratory of Sincrotron Light (LNLS), Campinas, Brazil, which is equipped with an asymmetrically cut and bent $\mathrm{Si}$ (111) monochromator $(\lambda=1.608 \AA)$ that yields and horizontally focused beam. A vertical one-dimensional position sensitive $\mathrm{x}$-ray detector and a multichannel analyzer were used to record the SAXD intensity, I(q), as a function of the modulus of the scattering vector $\mathrm{q}, \mathrm{q}^{1 / 4}(4 \pi / \lambda) \sin (\varepsilon / 2)$, $\varepsilon$ being the scattering angle. The parasitic scattering produced by slits was subtracted from the total scattering intensity. Both scattering intensity were recorded in relative units but, for a quantitative comparison, they were normalized to the same experimental conditions and equivalent sample thickness. Since the incident x-ray beam has a point-like cross-section at the detection plane and the width of resolution detector slit was small, no mathematical desmearing of the scattering curves was needed (Chorilli et al., 2011).

\section{Polarized light microscopy}

In this test a small aliquot translucent system, corresponding to two standardized $(0.1 \mu \mathrm{L})$ amounts were placed on glass microscope, to form a thin layer. These were analyzed by polarized light microscopy (polarized light microscope - type 102 - Motic), to investigate the presence of anisotropy, as an indicator of LCs (Chorilli et al., 2009; Engels, Rybinski, 1998).

\section{Rheological study}

The rheological behavior of liquid crystalline systems was determined with the aid of a rheometer Cone \& Plate (DVII + Viscometer - Brookfiel) coupled to a spindle C52, operating software V2.5 Wingather. The rheometries were performed at room temperature $\left(25^{\circ} \mathrm{C} \pm 2\right)$, in triplicate, with an amount of $0.2 \mathrm{~g}$ of translucent sample formulations. The formulations were analyzed for their rheological behavior at T0, T15 and T30 days after their preparations (Spellmeier, Heberlé, 2007).

\section{Assay texture}

For the analysis of texture profile concerning the formulations, the TA.XTplus Texture Analyzer (Stable Micro Systems. Surrey, England) was used. The test comprises two compression cycles of the sample, obtaining a curve of force versus time, from which it is possible to extract mechanical properties, e.g. hardness, compressibility, adhesion and cohesion. To perform the test, the formulations ( $15 \mathrm{~g})$ were initially placed in conical centrifuge tubes of $50 \mathrm{~mL}\left(\right.$ Falcon $\left.^{\circledR}, \mathrm{BD}\right)$, and centrifuged at $4000 \mathrm{rpm}$ for $10 \mathrm{~min}$ (Eppendorf 5810R) to remove any air bubbles. The tubing samples were fixed under analytical probe (10 $\mathrm{mm}$ diameter), which fell at a constant speed of $1 \mathrm{~mm} / \mathrm{s}$, in contact with the sample compressed to a constant speed of $0.5 \mathrm{~mm} / \mathrm{s}$ at a present depth $(10 \mathrm{~mm})$, and returned to the surface at a speed of $0.5 \mathrm{~mm} / \mathrm{s}$. After this first cycle, the device rested for 5 seconds and the second compression subsequently started (Jones, Woolfson, Brown, 1997a). All formulations were analyzed in triplicate at a temperature of $32^{\circ} \mathrm{C}$.

\section{Bioadhesion test}

The bioadhesion of formulations was evaluated by using the TA.XTplus Texture Analyzer (Stable Micro Systems ${ }^{\circledR}$ ), by the test "Hold Time Until". As experimental model, a domestic pig ear skin was used as purchased from a local slaughterhouse. The skin was previously separated from the cartilage and adipose tissue and dermatomized at $500 \mu \mathrm{m}$, by using a dermatometer (Nouvag TMC 300). Prior to testing, the skins were maintained in phosphate buffer solution, $\mathrm{pH} 7.4$ for 10 minutes, and hairs were clipped with scissors. A sample of $7.5 \mathrm{~g}$ of the formulation was transferred to a Falcon tube $\left(\mathrm{BD}^{\circledR}\right)$, which was centrifuged at $3500 \mathrm{rpm}$ for 3 minutes (Eppendorf 5810R) to remove air bubbles and to retain a flat surface. The skin was fixed to the probe with the aid of rubber ring; also, the Falcon tube was fixed below the probe. The test began with the probe descending at a speed of $1 \mathrm{~mm} / \mathrm{s}$ to contact formulation (detected with a trigger force of $2 \mathrm{mN}$ ), remaining in contact with the formulation for 60 seconds. The probe, then, was removed slowly at a speed of $0.5 \mathrm{~mm} / \mathrm{s}$, and the force exerted by the probe to highlight the skin surface of the formulation was determined by curve bioadhesive force versus time. Assays were performed in triplicate.

\section{In vitro unspecific cytotoxicity}

Mammal cytotoxicity of the formulations was studied in vitro using J-774 mouse macrophages as the cellular model. Cells were seeded at a density of $2.5-10.0 \times 10^{5}$ cells/well in 96-well plates flat bottom microplates (Nunclon) and exposed for $48 \mathrm{~h}$ to different doses of the formulations $(18.6,10,5$ and $1 \mu \mathrm{M})$ for control. After treatment, the compounds were removed and the cells washed once with PBS. Cell viability was then colorimetrically assessed by measuring the mitochondrialdependent reduction of MTT to formazan. For that purpose, the cells and MTT $(0.4 \mathrm{mg} / \mathrm{mL})$ were incubated in air at $37^{\circ} \mathrm{C}$ for $3 \mathrm{~h}$. After the incubation period, the supernatant 
was removed and formazan crystals were dissolved with DMSO $(180 \mu \mathrm{L})$. The plates were shaken for $10 \mathrm{~min}$ and the optical densities were measured at $560 \mathrm{~nm}$ in a multiwall spectrophotometer. Each concentration was assayed three times and six additional controls (cells in medium) were used in each test. The data were exhibited in $\%$ of cellular viability.

\section{Statistical analyses}

The data from the test physicochemical characterization and skin permeation and retention tests were evaluated by One-way ANOVA and Tukey post-test with significance level of $0.05 \%$. Analyses were performed using the Graph Pad Prism software, version 5.01, 2007.

\section{RESULTS AND DISCUSSION}

Liquid-crystalline systems (LCSs) were obtained for a combination of surfactants in concentrations 70 and $80 \%$. The compositions to obtain LCSs are shown in Table $\mathrm{I}$, indicating the concentration of the aqueous phase, the oil phase and the mixture of surfactants.

TABLE I - Components of the formulations in percent $(\% \mathrm{w} / \mathrm{w})$

\begin{tabular}{lccc}
\hline Samples & Oily & Surfactants & Water \\
\hline SLC 1 (S1) & 10 & 80 & 10 \\
SLC 2 (S2) & 10 & 70 & 20 \\
\hline
\end{tabular}

Figure 1 illustrates the ternary diagram of olive oil, distilled water and sorbitan monooleate ethoxylated combined with sorbitan monooleate 20 EO in 1:3 proportion. Translucent regions, phase separation, opaque, liquid and pasty were observed.

These findings relate to the surfactant concentration that ensured the obtaining of LCSs in the experimental reports of Gursoy and Benita (2004) and Kommuru et al. (2001), which also describe obtaining translucent systems with high concentrations of surfactants. Also in agreement with the studies presented by Kommuru and collaborators (2001), the employment of a mixture of nonionic surfactants, as in represents the mixture of sorbitan monooleate $\left(\operatorname{Span}^{\circledR} 80\right)$ and polyoxyethylene 20 sorbitan monooleate $\left(\right.$ Tween $^{\circledR} 80$ ) in 1:3 proportion, favors the decrease of surface tension of phases of the system, which enables the formation of translucent systems (SonnevilleAubrun, Simonnet, L'Alloret 2004).

The stabilization of formulations by the use of nonionic surfactants occurs through steric impediment and

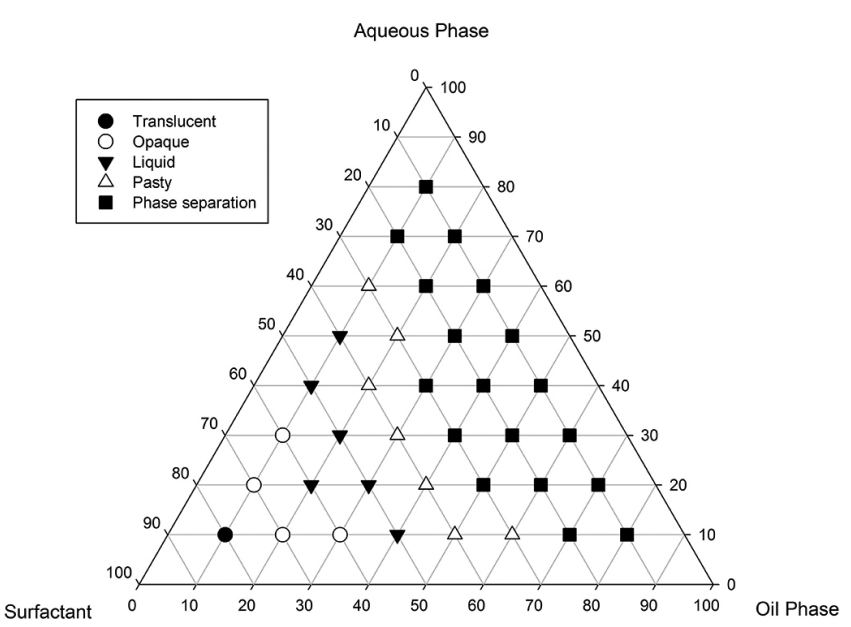

FIGURE 1 - Ternary diagram of the formulation with olive oil, sorbitan monooleate and polyoxyethylene 20 sorbitan monooleate in 1:3 proportion.

hydrogen bonding. Thus, the apolar part of the surfactant is incorporated into the oil droplets and hydrophilic groups in the aqueous phase. The hydrophilic groups, in turn, cause steric impediment which inhibits the oil droplets to coalesce, and forming hydrogen bonding with water (Silva, Soares, 1996). Besides, if the proportion of surfactant is increased, consequently the stabilization of formulation is larger, which provides a greater amount of liquid crystals in the formulation.

The combination of sorbitan monooleate and polyoxyethylene 20 sorbitan monooleate in 1:3 proportion is justifiable due to its low relative toxicities when compared with ionic surfactants, broad compatibility with various electrically chargeable compounds and due to obtaining values of EHL that optimize obtaining stabilized emulsion systems (Gursoy, Benita, 2004; Mou et al., 2008; Yilmaz, Borchert, 2006).

The olive vegetable oil chemically characterized by being composed of long-chain triglycerides, which are widely used in experimental prototypes for the development of LCSs, due to its chemical structure, favoring the formation of LCSs due to it interaction established with the surfactant (Djekic, Primorac, 2008).

The liquid crystals search was performed using polarized light microscope. It was observed, as shown by Figures 2 and 3, that all formulations classified as translucent exhibited liquid crystals (LCs) with lamellar structures, described as "Maltese Crosses", until the last analysis time (T30). While possible, as reported in Chorilli et al. (2009), there was no structural alterations in the liquid-crystalline systems until the last analysis time, then, all formulations remained with lamellar liquid-crystalline structures ("Maltese Cross"). 
Thus as evidenced by Engels and Rybinski (1998), and Formariz et al. (2005), the presence of liquidcrystalline structures in a system (formulation) may contribute to several aspects. Among the main highlights are: the improved physical and chemical stability of the system, the visual aspect, since LCs exhibit a property conceived as thermochromism; protection to the photo and thermodegradation when active substances are effectively incorporated into arrays of LCs, the increased capacity to retain water in the stratum corneum providing increased skin hydration (Chorilli et al., 2003; Masson, 2005; Santos et al., 2006). The Figures 2 and 3 illustrate the presence of crystals in translucent formulations until last analysis time.

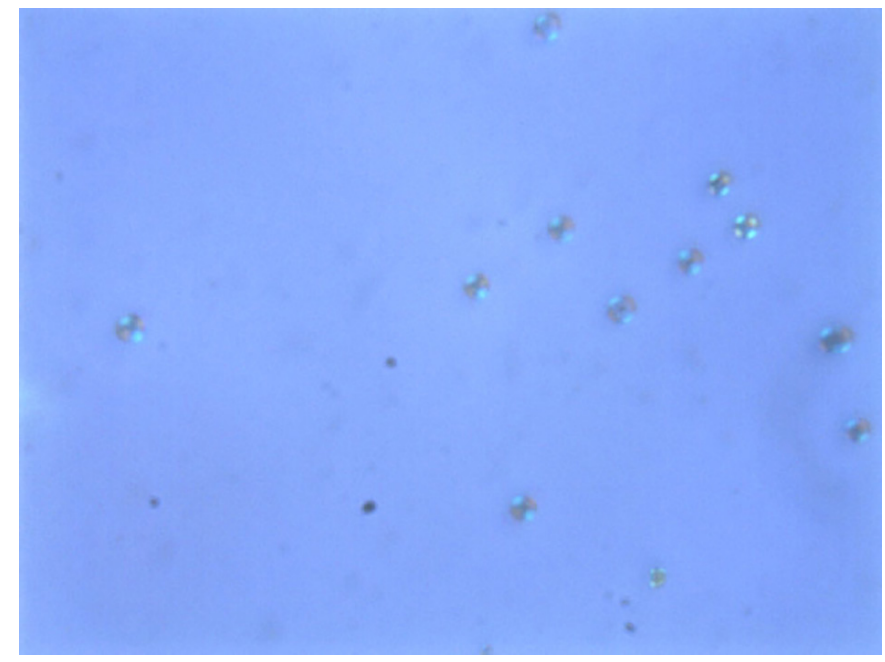

FIGURE 2 - Photomicrograph under polarized light LCS 1, after 30 days of its preparation, under 400x magnification.

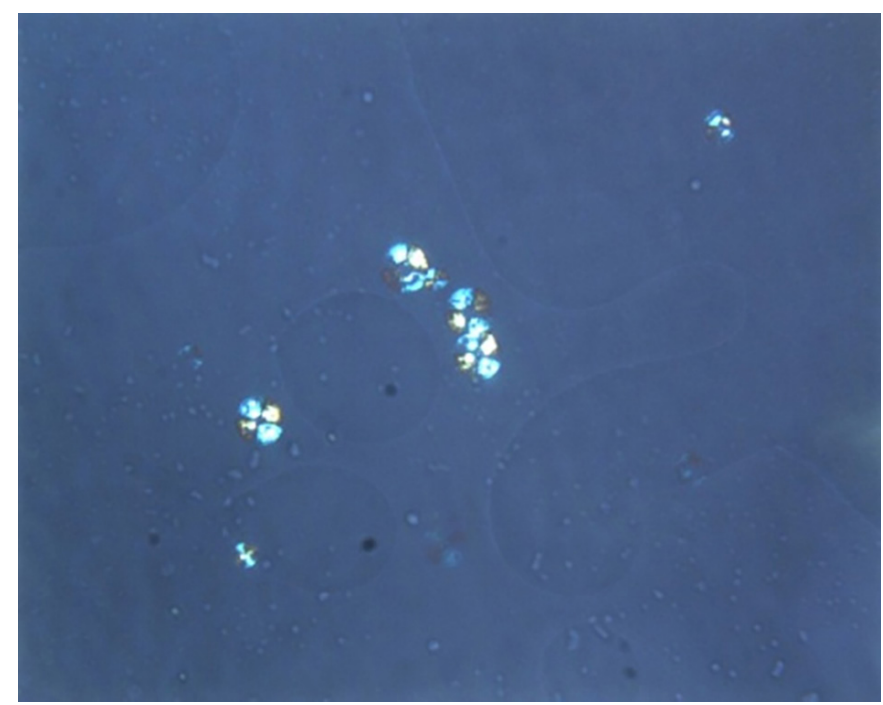

FIGURE 3 - Photomicrograph under polarized light LCS 2, after 30 days of its preparation, under 400x magnification.
The SAXS curves for liquid crystalline systems show peaks, whose number and location allow to determine the type of arrangement that the atoms form in the matrix (Chorilli et al., 2011). The present results show the structure of the liquid crystal to be lamellar with the amopiphilic sheets separated by solvent as shown by two or more peaks, the distances betweem them in accordance with the rules of distances as 2, 3, and 4, respectively (Chorilli et al., 2009). Figure 4 is evidence that, independent of the systems, only the presence of lamellar phases was observed, which is most convenient for dermal and transdermal systems (Chorilli et al., 2011). The liquid crystal lamellar kind is responsible to increase the stability because the lamellar structures make a protection around the globules, inhibiting the adhesion and the coalescence (Morais, 2006; Morais et al., 2005).

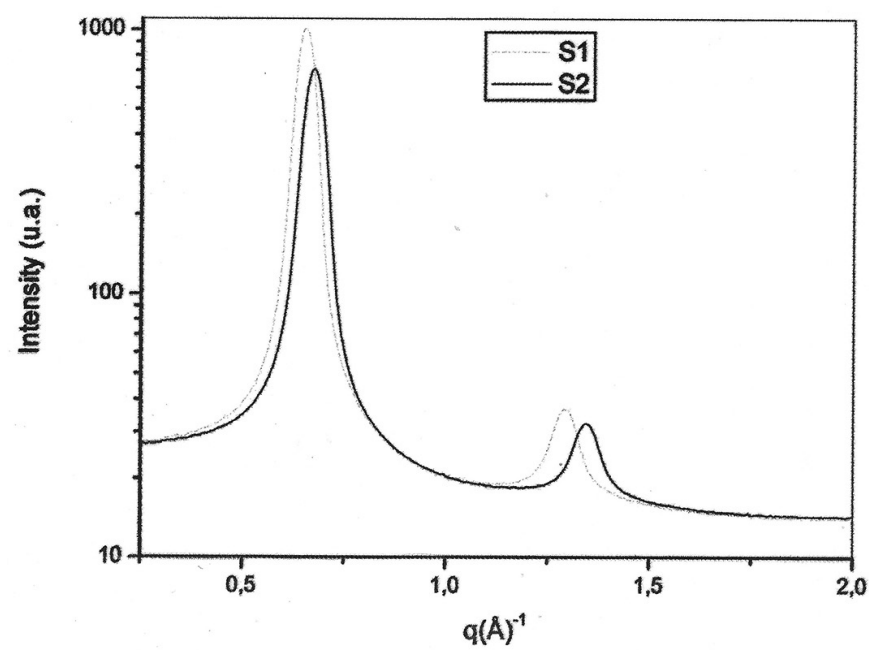

FIGURE 4 - SAXS curves for systems S1 and S2.

The use of non-ionic surfactants, according Santos et al. (2006), can promote the formation of liquid-crystalline phase. According to Morais (2006), the liquid crystals are formed also in the presence of rheological modifiers such as stearyl alcohol, cetyl alcohol and cetostearyl alcohol. The long chain fatty alcohols, in the presence of non-ionic surfactant, can form lamellar mesophases due to position themselves between the surfactant molecules. Morais (2006) reports that the lipophilic surfactant (stearyl and stearic acid) long chain saturated obtains more stable emulsions, as the long chain penetrates deeper into the oil droplet been less rigid with respect to rotation than a chain oleic which features double bond, besides presenting polar portion reduced in respect of oleates, being favorable to the formation of lamellar phases.

The flow index can provide information about the rheological behavior shown by the formulation in response 
to stress. The average values concerning the flow index of liquid crystalline systems (Table II) reveal no significant changes during the time of analysis (T7, T15 and T30), while allowing classifying the systems rheologically in pseudoplastic behaviour (where $\dot{\eta}<1$, and $\dot{\eta}=$ flow index). The pseudoplastic behavior is considered suitable for topical products, because after the application of a shear force, initial resistance for cosmetic flow decreases, reflecting the best application and spreadability of the product, as well as optimizing the sensory thereof(Morais et al., 2005).

TABLE II - Average values for the flow index of the systems

\begin{tabular}{lccc}
\hline \multirow{2}{*}{ Systems } & \multicolumn{3}{c}{ Average - Flow Index $(\mathbf{n}=\mathbf{3})$} \\
\cline { 2 - 4 } & Time 7 days & Time 15 days & Time 30 days \\
\hline System 1 & $0,72 \pm 0,01$ & $0,68 \pm 0,03$ & $0,67 \pm 0,03$ \\
System 2 & $0,76 \pm 0,02$ & $0,64 \pm 0,04$ & $0,59 \pm 0,04$ \\
\hline
\end{tabular}

Table III shows that for both systems studied there was loss of viscosity, particularly after 15 days of preparation of the formulations. It also appears that the system 1 had higher viscosity than the second system over the higher surfactant concentration provided in this.

TABLE III - Average values for apparent viscosity of the systems

\begin{tabular}{llll}
\hline \multirow{2}{*}{ Systems } & \multicolumn{3}{l}{ Average -Apparent Viscosity $(\mathbf{n}=\mathbf{3})$} \\
\cline { 2 - 4 } & Time 7 days & Time 15 days & Time 30 days \\
\hline System 1 & $929 \pm 25,71$ & $665 \pm 71,68$ & $680 \pm 68,11$ \\
System 2 & $644 \pm 67,83$ & $522 \pm 32,42$ & $511 \pm 28,86$ \\
\hline
\end{tabular}

The thixotropy can be illustrated by hysteresis area between the ascending and descending curves of a graph representing the relationship between the shear rate and shear stress (Almeida, Bahia, 2003). Figures 5 and 6 show the rheograms obtained for liquid-crystalline systems.

In turn, provided through the rheograms (Figures 5 and 6), it can be observed little evidence of thixotropy of these formulations at all analysis times (T7, $\mathrm{T} 15$ and T30). Thus, these systems tend to have a rapid recovery of its original rheological characteristics after

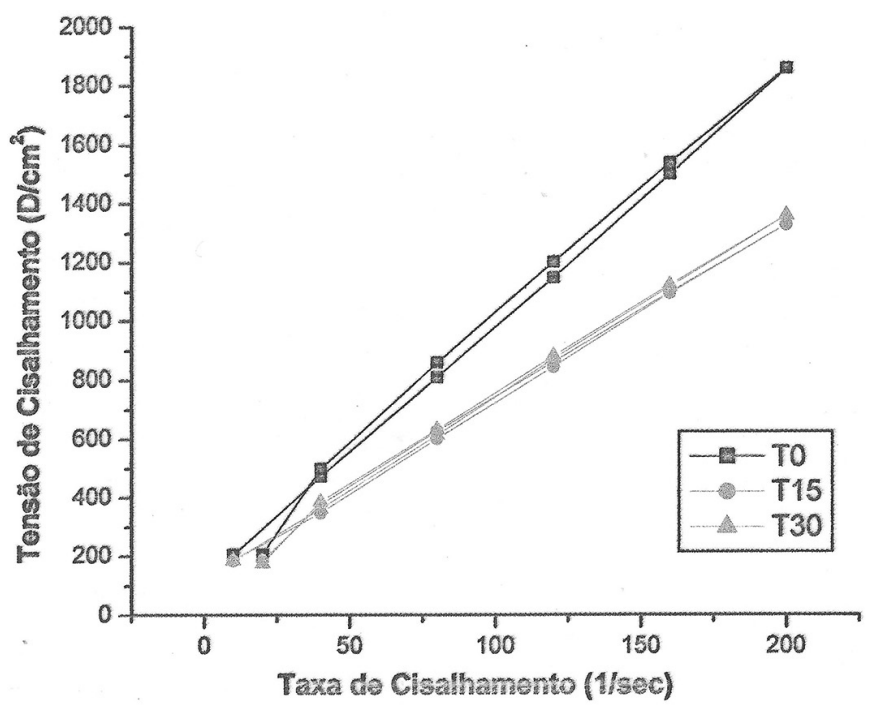

FIGURE 5 - System 1 Rheogram.

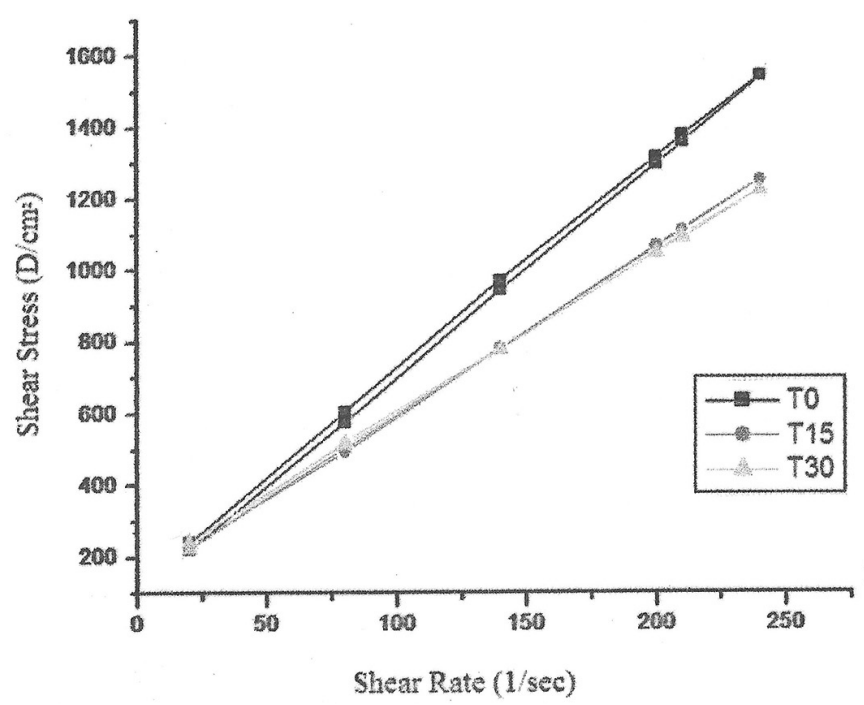

FIGURE 6 - System 2 rheogram.

termination of the force applied on the formulations over time (Almeida, Bahia, 2003).

The mechanical properties of the systems such as hardness, compressibility, adhesiveness and cohesiveness are presented in Table IV.

These mechanical parameters analyze the stressstrain behavior of the formulations, with the possibility to predict the effects on the stresses encountered in

TABLE IV - Mechanical properties of the formulations under study

\begin{tabular}{lcccc}
\hline Samples & Hardness & Compressibility (kg.s) & Adhesiveness (kg.s) & Cohesiveness \\
\hline SLC 1 (S1) & $8.151 \pm 0.768$ & $0.117 \pm 0.011$ & $0.040 \pm 0.004$ & $0.641 \pm 0.0358$ \\
SLC 2 (S2) & $20.739 \pm 1.805$ & $0.287 \pm 0.023$ & $0.132 \pm 0.016$ & $0.688 \pm 0.0339$ \\
\hline
\end{tabular}


physiological conditions of the formulations (Jones, Woolfson, Brown, 1997b; Senyigit et al., 2011), becoming an indispensable tool in the study of drug delivery systems for choosing the most appropriate formulation.

Using ANOVA, the formulations SLC1 (S1) and SLC2 (S2) have properties of hardness, compressibility, adhesion and cohesion similar statistically $(\mathrm{p}<0.05)$, indicating that the increased amount of water in S2 did not interfere with the mechanical properties of the systems.

The values found for the parameter bioadhesive force of the formulations studied are shown in Table V.

TABLE V - Values obtained for the parameter bioadhesive force of the formulations under study.

\begin{tabular}{lc}
\hline Samples & Bioadhesive force $(\mathbf{N} \pm$ DP) \\
\hline SLC 1 (S1) & $0.043 \pm 0.002$ \\
SLC 2 (S2) & $0.081 \pm 0.070$ \\
\hline
\end{tabular}

Using ANOVA, the formulations SLC1 (S1) and SLC2 (S2) have properties of bioadhesive force similar statistically $(\mathrm{p}<0.05)$, indicating that the increased amount of water in S2 did not interfere with the bioadhesive properties of the systems.

It was performed in vitro cytotoxicity of the formulations using J-774 mouse macrophages as the cellular model. The data were exhibited in $\%$ of cellular viability, according to Figure 7.

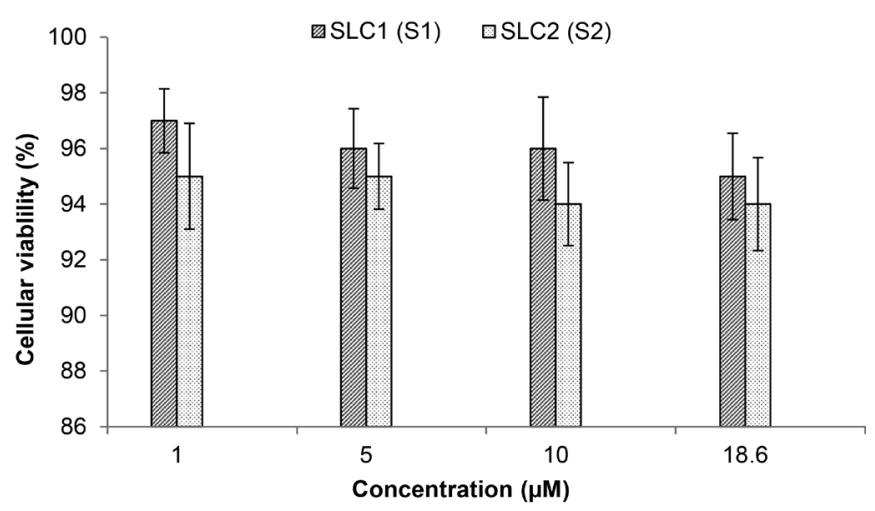

FIGURE 7 - \% Cellular viability to SLC1 (S1) and SLC2 (S2).

The assay results of $\%$ cellular viability showed that the formulations were not able to kill normal cells macrophages, all of them exhibited cellular viability upper that $94 \%$.

\section{CONCLUSION}

It concluded that it was possible to obtain LCSs with the mixture of two non-ionic surfactants, distilled water and olive oil. It was also found that different concentrations of the constituents of the formulation influence the viscosity. Furthermore, both systems showed pseudoplastic behavior and the absence of thixotropy that are adequate for topical use. The texture and bioadhesion assays showed that formulations were similar statistically $(p<0.05)$, indicating that the increased amount of water in S2 did not interfere with the bioadhesive properties of the systems. In vitro cytotoxic assays showed that formulations didn't present cytotoxicity. Olive oil-based systems may be a promising platform for skin delivery of drugs.

\section{LIST OF ABBREVIATIONS}
LCS - Liquid-Crystalline System
LCSs - Liquid-Crystalline Systems
LCs - Liquid Cystals

\section{ACKNOWLEDGEMENTS}

The authors wish to thank the FAPESP and CNPq for the financial support.

\section{REFERENCES}

ALMEIDA, I.; BAHIA, M.F. Reologia: interesse e aplicações na área cosmética-farmacêutica. Cosmet. Toil., v.15, n.3, p.96-100, 2003.

BECHTOLD, I.H. Liquid crystals: a complex system of simple application. J. Braz. Phys. Soc., v.27, n.3, p.333-342, 2005.

BRUMMER, R.; GODERSKY, S. Rheological studies to objectify sensations occuring when cosmetic emulsions are applied to the skin. Colloids Surf. A: Physicochem. Eng. Aspects, v.152, n.1/2, p.89-94, 1999.

CHORILLI, M.; PRESTES, P.S.; RIGON, R.B.; LEONARDI, G.R.; CHIAVACCI, L.A.; SARMENTO, V.H.V.; SCARPA, M.V. Desenvolvimento de sistemas líquido-cristalinos empregando silicone fluído de co-polímero glicol e poliéter funcional siloxano. Quím. Nova, v.32, n.4, p.1036-1040, 2009. 
CHORILLI, M.; PRESTES, P.S.; RIGON, R.B.; LEONARDI, G.R.; CHIAVACCI, L.A.; SARMENTO, V.H.V.; SCARPA, M.V. Structural characerization and in vivo evaluation of retynil palmitote in non-ionic lamellar liquid crystalline system. Colloids Surf., B., v.85, n.2, p.182-188, 2011.

CHORILLI, M.; RIBEIRO, M.C.A.P.; POLAXOW, M.L.O.; CAMPOS, M.S.P.; LEONARDI, G.R. Efeito de bases dermocosméticas na hidratação da pele. Cosm. Toil., v.15, p.56-58, 2003.

CHORILLI, M.; ZAGUE, V.; SCARPA, M.V.; LEONARDI, G.R. Influência da viscosidade do veículo na liberação in vitro da cafeína. Rev. Eletr. Farm., v.4, p.52-60, 2007.

CORRÊA, N.M.; CAMARGO JUNIOR, F.B.; IGNÁCIO, R.F.; LEONARDI, G.R. Avaliação do comportamento reológico de diferentes géis hidrofílicos. Rev. Bras. Cienc. Farm., v.41, n.1, p.73-76, 2005.

D'ANGELO, S.; INGROSSO, D.; MIGLIARDI, V.; SORRENTINO, A.; DONNARUMMA, G.; BARONI, A.; MASELLA, L.; TUFANO, M.A.; ZAPPIA, M.; GALLETTI, P. Hydroxytyrosol, a natural antioxidant from olive oil, preventsprotein damage induced by long-wave ultraviolet radiation in melanoma cells. Free Radical Biol. Med., v.38, n.7, p.908-919, 2005.

DJEKIC, L; PRIMORAC, M. The influence of cosurfactants and oils on the formation of pharmaceutical microemulsions based on PEG-8 caprylic/capric glycerides. Int. J. Pharm., v.352, n.1/2, p.231-239, 2008.

ELIAS, P.M. Stratum corneum defensive functions: an integrated view. J. Invest. Dermatol., v.125, n.2, p.183$200,2005$.

ENGELS, T.; RYBINSKI, W.V. Liquid crystalline surfactant phases in chemical applicantions. J. Mater. Chem., v.8, p.1313-1320, 1998.

FORMARIZ, T.P.; URBAN, M.C.C.; SILVA JÚNIOR, A.A.; GREMIÃO, M.P.D.; OLIVEIRA, A.G. Microemulsões e fases líquidas cristalinas como sistemas de liberação de fármacos. Rev. Bras. Cienc. Farm., v.41, n.3, p.53-58, 2005.

GURSOY, R.; BENITA, S. Self-emulsifying drug delivery systems (SEDDS) for improved oral delivery of lipophilic drugs. Biomed. Pharmacother., v.58, n.3, p.173-182, 2004.
JONES, D.S.; WOOLFSON, A.D.; BROWN, A.F. Textural analysis and flow rheometry of novel, bioadhesive antimicrobial oral gels. Pharm. Res., v.14, n.4, p.450-457, 1997a.

JONES, D.S.; WOOLFSON, A.D.; BROWN, A.F. Textural, viscoelastic and mucoadhesive properties of pharmaceutical gels composed of cellulose polymers. Int. J. Pharm, v.151, n.2, p.223-233, $1997 \mathrm{~b}$.

KOMMURU, T.R.; GURLEY, B.; KHAN, M.A.; REDDY, I.K. Self-emulsifying drug delivery systems (SEDDS) of coenzyme Q10: formulation development and biovailability assessment. Int. J. Pharm., v.212, n.12, p.233-246, 2001.

LEONARDI, G.R.; GASPAR, L.R.; MAIA CAMPOS, P.M.B.G. Estudo da variação do $\mathrm{pH}$ da pele humana exposta à formulação cosmética acrescida ou não das vitaminas $\mathrm{A}, \mathrm{E}$ ou de ceramida, por metodologia não invasiva. An. Bras. Dermat., v.77, n.5, p.563-569, 2002.

MASSON, D.S. Polyhydroxy alcohol and peach oil addition influence on liquid crystal formation and rheological behavior of O/W emulsion. J. Dispersion Sci.Technol., v.26, p.463-468, 2005.

MORAIS, G.G. Desenvolvimento e avaliação da estabilidade de emulsões $\mathrm{O} / \mathrm{A}$ com cristais líquidos acrescidos de xantina para o tratamento da hidropolisdistrofia ginóide (celulite). Ribeirão Preto, 2006. 152p. [Dissertation of Master degree. Faculty of Pharmaceutical Sciences. University of São Paulo].

MORAIS, G. G.; SANTOS, O.D.H.; MASSON, D.S; OLIVEIRA, W.P.; ROCHA FILHO, P.A. Development of $\mathrm{O} / \mathrm{W}$ emulsions with annato oil (Bixa orellana) containing liquid crystal. J. Dispers. Sci. Technol., v.26, n.5, p.591$596,2005$.

MOU, D.; CHEN, H.; DU, D.; MAO, C.; WAN, J.; XU, H.; YANG, X. Hydrogel-thickened nanoemulsion system for topical delivery of lipophilic drugs. Int. J. Pharm., v.353, n.1-2, p.270-276, 2008.

MULLER-GOYMANN, C.C. Physicochemical characterization of colloid drug delivery systems such as reserve micelles, vesicles, liquid crystals and nanoparticles for topical administration. Eur. J. Pharm. Biopharm., v.58, n.2, p.343$356,2004$. 
NESSEEM, D.I. Formulation and evaluation of itraconazole via liquid crystal for topical delivery system. J. Pharm. Biomed. Anal., v.26, n.3, p.387-399, 2001.

REBELLO, T.F.S. O operador e a reologia. Cosm. Toil., v.17, p.32, 2005.

SANTOS, F.K.; OYAFUSO, M.H.; KILL, C.P.; GREMIÃO, M.P.D.; CHORILLI, M. Nanotechnology-based drug delivery systems for treatment of hyperproliferative skin diseases: a review. Curr. Nanosci., v.9, n.1, p.159-167, 2013.

SANTOS, O.D.H.; CAMARGO, M.F.P.; ANDRADE, F.F.; ROCHA FILHO, P.A. Study of liquid-crystalline phase changes during evaporation in vegetable oil emulsions. $J$. Dispersion Sci. Technol., v.27, n.7, p.997-1001, 2006.

SANTOS, O.D.H.; MIOTTO, J.V.; MORAIS, J.M.; ROCHA FILHO, P.A. Attainment of emulsions with liquid crystal from marigold oil using the required HLB method. J. Dispersion Sci. Technol., v.26, n.2, p.243-249, 2005.

SENYIGIT, T.; TEKMEN, I. SONMEZ, U.; SANTI, P.; OZER, O. Deoxycholate hydrogels of betamethasone-17-valerate intended for topical use: in vitro and in vivo evaluation. Int. J. Pharm., v.403, n.1/2, p.123-129, 2011.

SILVA, E.C.; SOARES, I.C. Tecnologia de emulsões. Cosm. Toil., v.5, p.37-46, 1996.

SONNEVILLE-AUBRUN, O.; SIMONNET, J.T.; L'ALLORET, F. Nanoemulsions: a new vehicle for skincare products. $A d v$. Colloid Interface Sci., v.20, p.108-109, 2004.

SOUZA, A.L.R.; KIILL, C.P.; SANTOS, F.K.; LUZ, G.M.; CHORILLI, M.; GREMIÃO, M.P.D. Nanotechnologybased drug delivery systems for dermatomycosis treatment. Curr. Nanosci., v.8, n.4, p.512-519, 2012.
SPELLMEIER, F.; HEBERLÉ, G. Bases emulsionadas: comparativo de estabilidade acelerada. Cosm Toil., v.19, p.68-70. 2007.

TOFANI, D.; BALDUCCI, V.; INCERPI, S.; GAMBACORTA, A. Fatty acid hydroxytyrosyl esters: structure/antioxidant activity relationship by ABTS and in cell-culture DCF assays. J. Agric. Food Chem., v.58, n.9, p.5292-5299, 2010.

TYLE, P. Liquid crystals and their applications in drug delivery. In: ROSOFF, M., ed. Controlled release of drugs: polymers and aggregate systems. New York: VCH Publishers, 1989. chap.4, p.125-162.

VISIOLI, F. Antioxidant and other biological activities of olive mill waste waters. J. Agric. Food Chem., v.47, n.8, p.33973401, 1999.

VISIOLI, F.; BELLOMO, G.; GALLI, C. Free radicalscavenging properties of olive oil polyphenols. Biochem. Biophys. Res. Commun., v.247, n.1, p. 60-64, 1998.

VISIOLI, F.; CARUSO, D.; PLASMATI, E.; PATELLI, R.; MULINACCI, N., ROMANI, A., GALLI, G., GALLI, C. Hydroxytyrosol, as a component of olive mill waste water, is dose- dependently absorbed and increases the antioxidant capacity of rat plasma. Free Radical Biol. Med., v.34, n.3, p.301-305, 2001.

YILMAZ, E.; BORCHERT, H. Effect of lipid-containing, positively charged nanoemulsions on skin hydration, elasticity and erythema - an in vivo study. Int. J. Pharm., v.307, n.2, p.232-238, 2006.

Received for publication on $31^{\text {st }}$ December 2014 Accepted for publication on $1^{\text {st }}$ September 2015 
